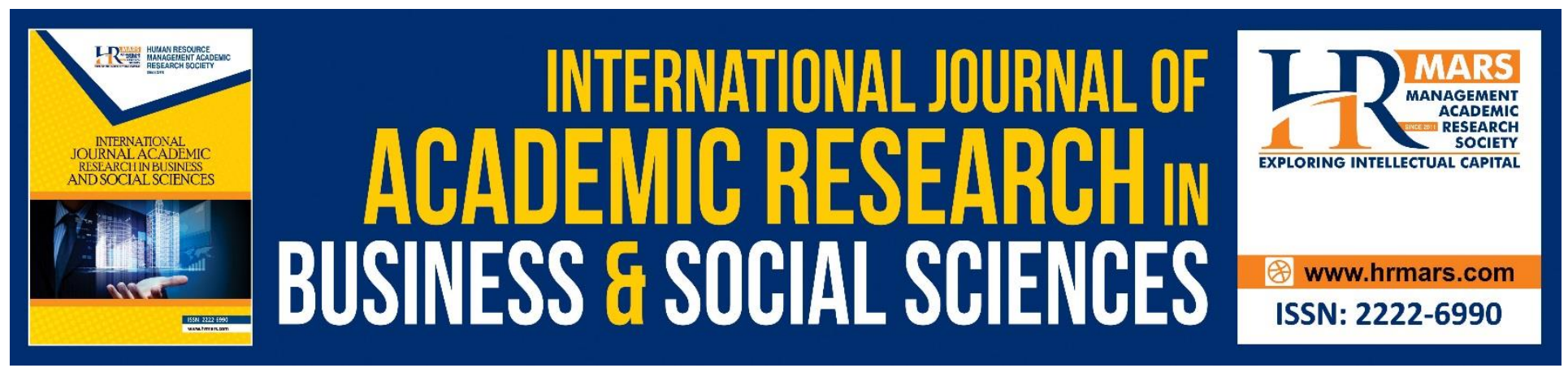

\title{
Symmetrical Design Analysis of Malay Arts in Ethnomathematics Context
}

Rushana Sulaiman @ Abd Rahim, Mat Redhuan Samsudin, Halim Husain

To Link this Article: http://dx.doi.org/10.6007/IJARBSS/v10-i9/7984

DOI:10.6007/IJARBSS/v10-i9/7984

Received: 18 June 2020, Revised: 17 July 2020, Accepted: 19 August 2020

Published Online: 29 September 2020

In-Text Citation: (Abd Rahim, Samsudin, \& Husain, 2020)

To Cite this Article: Abd Rahim, R. S@., Samsudin, M. R., \& Husain, H. (2020). Symmetrical Design Analysis of Malay Arts in Ethnomathematics Context. International Journal of Academic Research in Business and Social Sciences. 10(9), 1047-1060.

\section{Copyright: (C) 2020 The Author(s)}

Published by Human Resource Management Academic Research Society (www.hrmars.com)

This article is published under the Creative Commons Attribution (CC BY 4.0) license. Anyone may reproduce, distribute, translate and create derivative works of this article (for both commercial and non-commercial purposes), subject to full attribution to the original publication and authors. The full terms of this license may be seen at: http://creativecommons.org/licences/by/4.0/legalcode

Vol. 10, No. 9, 2020, Pg. 1047 - 1060 http://hrmars.com/index.php/pages/detail/IJARBSS

Full Terms \& Conditions of access and use can be found at http://hrmars.com/index.php/pages/detail/publication-ethics 


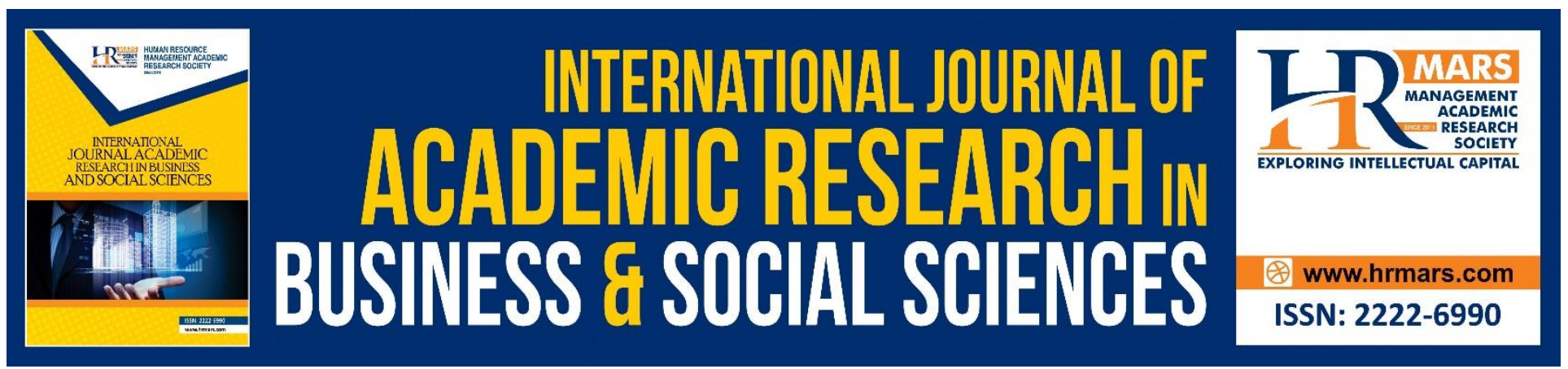

\title{
Symmetrical Design Analysis of Malay Arts in Ethnomathematics Context
}

\author{
Faculty of Art and Design, MARA University of Technology, Malaysia \\ Email: rushana@uitm.edu.my,redhuansamsudin@uitm.edu.my \\ Halim Husain \\ Postgraduate Studies, ASWARA, Malaysia \\ Email: abdulhalim@aswara.edu.my
}

Rushana Sulaiman @ Abd Rahim, Mat Redhuan Samsudin

\begin{abstract}
Th paperwork aims to examine the meaning allude to Malay art concept through mathematical aspects and thinking. It can be seen on carvings, weaving, painting, architecture and textile. Pattern and motifs in Malay art works are rich with mathematical values which can be seen on any geometric designs. This is a qualitative research that analyses symmetry. Art designs was analysed in formalistic context in order to explain symmetry concepts that exist in ethnomathematics. Written and visualised data are gathered and collected via documentation, recording and observation. The findings of this study showed that the inter-relationships between art and mathematic cannot be denied through the beauty of art works as well as its beauty in mathematical aspects. The implication of this research is to view and see art not only from the angle of arts appreciation, but can be expanded to various philosophical perspectives especially in mathematical aspects.
\end{abstract}

Keywords: Symmetry, Art Appreciation, Malay Arts, Ethnomathematics.

\section{Introduction}

Mathematics appears in various fields, such as literature, economy, culture, philosophy and one of them is art. Most areas of art involve the use of mathematical concepts applied through thinking and skills. It has long existed among art activists to produce a combination of motifs or patterns that display the beauty and are symmetrical. Malay civilization history shows mathematical thinking born from the culture and system value of certain ethnics. Hence, the study of culture and mathematics are known with the term ethnomathematics.

In art of Malay heritage, the manifestation of ethnomathematics affects the society's background when it comes to works of art that include the creation of sculpture art, weaving art, painting art, architecture and textile art. It proves that art activists have high intellectual power in their production. The concept of mathematics in the artworks can be seen through the implicit meaning 
via subtle and meticulous compositions and patterns. This demonstrates the concept of mathematics through continuous, patterned, symmetrical and uniform mapping. It can be seen on Songket weaving, Mengkuang weaving, carpentry, wood carving and crafts. Artwork requires skills, creativity, thinking and knowledge that relates to the realm of life (Shuhaimi et al., 2011).

The concept of symmetry is the principle of harmony in displaying the beauty of nature. This principle underlies the unity of the law of attraction and it is the principle that underlies the structure and composition in the processing of a creation produced in the history of human civilization. The principle of symmetry is usually found in the artworks that highlights the value of Islamic in Malay. The elements of symmetry can be found in an object that includes the axis, points and planes. It can be seen in a plane that is divided into two parts known as symmetric planes (mirrors and reflections), lines or axes of symmetry (Khairuddi et al, 2004; Ashraf, 2001).

\section{The Purpose of The Study}

This paper carried out to identify the existence of the concept of symmetry through the work of Malay art from aspect and from the eye of ethnomathematics' thoughts. Symmetry analysis is conducted to classify mathematical notation symbols to classify symmetry in pattern design to create a good study. It also aims to examine the factors that support the relationship between the principle of equality in the creation of Malay art.

\section{Research Methodology}

A qualitative study approach that uses asymmetrical analysis case study design, it focuses on shapes, patterns and motifs in carving, weaving, painting, construction and textiles. There are three methods of data collection used, which are observation, visual recording and documentation analysis. Data were collected based on empirically-based fieldwork data obtained while in the field.

\section{Symmetrical Design Analysis Of Malay Arts \\ 1) The Art Of Weaving}

Geometric design can be seen in the art of weaving. Malay weaving has a decorative technique known as a kelarai. The design of this pattern is revealed through the thinking of weavers through the art of mengkuang weaving mats, pandan mats, food covers and walls using bamboo or mengkuang (Siti Zainon Ismail, 2018). For example, Mengkuang weaving mats and food cover that based on geometric shapes as shown in the table below: 
INTERNATIONAL JOURNAL OF ACADEMIC RESEARCH IN BUSINESS AND SOCIAL SCIENCES

Vol. 10, No. 9, 2020, E-ISSN: 2222-6990 @ 2020 HRMARS

Table 1. Kelarai Mata Bilis Weaving

\begin{tabular}{l|c|c|}
\hline \multicolumn{3}{c}{ Kelarai based on geometric shapes } \\
\hline
\end{tabular}

Table 1 shows the motifs and patterns produced are guided by life in the weaving environment which is translated into geometric shapes by applying the concepts of symmetry. The shape identified is found in the sample of mengkuang weaver mat above is in the pattern of Kelarai Ikan Bilis, which is a square-shape. Patterns are intertwined alternately leaving an original geometric effect (Mat Rofa et al., 2012). Table 1 also explains the concept of symmetry of the process of repetition of images through horizontal reflection. Rectangular Motifs (objects) are reflected on the reflection axis and produce a rectangular motifs (image) in reverse without changing the original shape.

The pattern arrangement shows the concept of continuous, patterned, symmetrical and uniform mapping. The artistic art applied to the weaving motifs of Kelarai Ikan Bilis shows that weavers can embody the skills highlighted through the colour, arrangement of patterns and the subtlety of their handicrafts.

Table 2. Kelarai Bunga Pecah Lapan weaving motifs

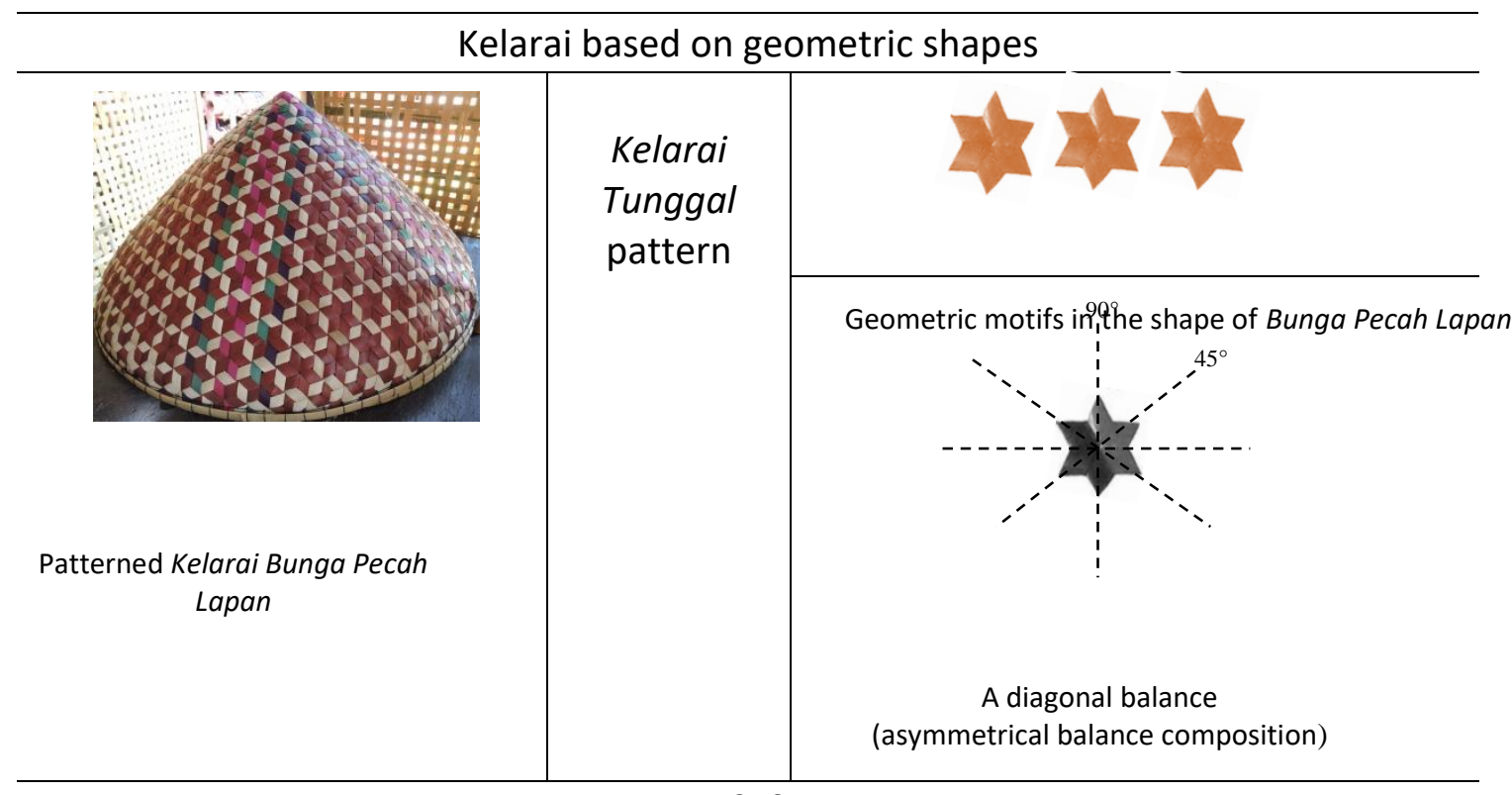


INTERNATIONAL JOURNAL OF ACADEMIC RESEARCH IN BUSINESS AND SOCIAL SCIENCES Vol. 10, No. 9, 2020, E-ISSN: 2222-6990 @ 2020 HRMARS

While Table 2 shows the weaving of the food cover in the pattern of Kelarai Bunga Pecah Lapan. There are four axes of symmetry forming eight angles where each repetition of the pattern produces an angle of $45^{\circ}$ around the centre point with a rotation of $360^{\circ}$. It is to form a single pattern that has a diagonal balance through asymmetrical balance composition. The geometric weaving pattern of a food cover is made by a specific technique called three-axis and hexagonal weaving. The shape of the food cover as a 3-dimensional cone, symmetrical parallelogram mosaic pattern is considered integration of mathematical ideas with the traditional culture of weaving food cover.

The beauty of the Kelarai is produced from a very simple arrangement of motifs and patterns to a pack pattern, and it is the result of a combination of more than two forms in one Kelarai. This design is used to cover foods that have a balanced geometric element so that it can stand firmly (Zamri et al., 2014).

Table 3. Kelarai Tunggal weaving motifs

\begin{tabular}{|c|c|c|}
\hline \multicolumn{3}{|c|}{ Kelarai based on geometric shapes } \\
\hline Kelarai Bunga Durian Motifs & $\begin{array}{l}\text { Kelarai } \\
\text { Tunggal } \\
\text { Pattern }\end{array}$ & $\begin{array}{l}\text { Repetition of angular patterns around the } \\
\text { center point to form a single pattern }\end{array}$ \\
\hline
\end{tabular}

Table 3 shows the Kelarai Tunggal motif, which is a repetitive pattern movement around the centre point of the line. There are four axes of symmetry forming eight angles where each repetition of the pattern produces an angle of $45^{\circ}$ around the centre point with a rotation of $360^{\circ}$. This kelarai pattern is produced by the weaver carefully to ensure symmetrical balance on each part of the pattern. Repetition of linear symmetrical patterns vertically and horizontally to form a Kelarai Tunggal pattern that results in repetition of the same property. The use of symmetry aims to understand the beauty in the arrangement of Kelarai Bunga Durian motives through the Kelarai Tunggal pattern, as shown in the table above.

Table 4. Two Dimension Kelarai Weaving.

\begin{tabular}{c|c|c|c}
\hline \multicolumn{3}{c}{ Kelarai based on geometric shapes } \\
\hline Kelarai Beras Patah Motifs & $\begin{array}{c}\text { Two } \\
\text { dimension } \\
\text { Kelarai }\end{array}$ & $\begin{array}{c}\text { Pattern repetition involves two or more } \\
\text { directions. } 360^{\circ} \text { rotation results from four } 90 \\
\text { ० rotations. }\end{array}$ \\
\hline
\end{tabular}


INTERNATIONAL JOURNAL OF ACADEMIC RESEARCH IN BUSINESS AND SOCIAL SCIENCES Vol. 10, No. 9, 2020, E-ISSN: 2222-6990 @ 2020 HRMARS

Kelarai Beras Patah is in the two dimension Kelarai category which shows the repetition of a pattern as if having a movement in the resulting arrangement involving two or more directions. It is a $360^{\circ}$ pattern rotation using four $90^{\circ}$ rotation as in Table 4 above. It also forms a counter pattern as a result of the arrangement and colour used. While in the repetition of the design of Kelarai Beras Patah, the movement shown is more random. The effect produced by the repetition of patterns in non-parallel shadows gives a variety of visual effects to be interpreted. The Kelarai Beras Patah pattern can be interpreted as an overlap of two symmetrical lines. The repetition of symmetrical lines in a vertical and horizontal pattern has formed a pattern. It involves repeating the patterned shadow four times or more easily referred to as the shadow pattern around the centre point of the Kelarai pattern. Each repetition has a different nature from the original pattern.

\section{2) Analysis of the Siri Nurani Paintings}

Figure 1. Siri Nurani

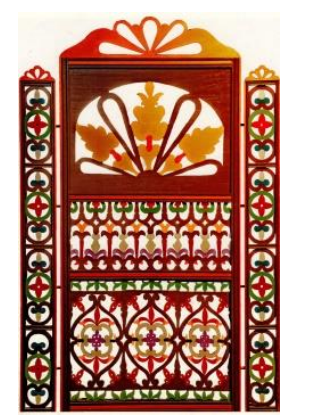

Siri Nurani (1996)

Ruzaika Omar Basaree

Ukiran kayu dan cat emulsi

$203 \times 81 \mathrm{~cm}$

Sumber: Balai seni visual Negara

Siri Nurani paintings artwork (1996) highlights the Malay-Muslim cultural styles that apply geometric motifs. This work is presented in a symmetrical manner with the method of repetition according to Ethnomathematics aesthetic principles that give implicit and implicit meaning about the concept of Awan Larat (Ruzaika Omar Basaree, 2016). The combination of several geometric motifs not only forms the identity of creation, but it shows the creativity of the artist. These motifs have been categorized to be identified and analyzed as geometric elements through the paintings of the Siri Nurani, namely:

Table 5. Tangent Circle Motif by Siri Nurani

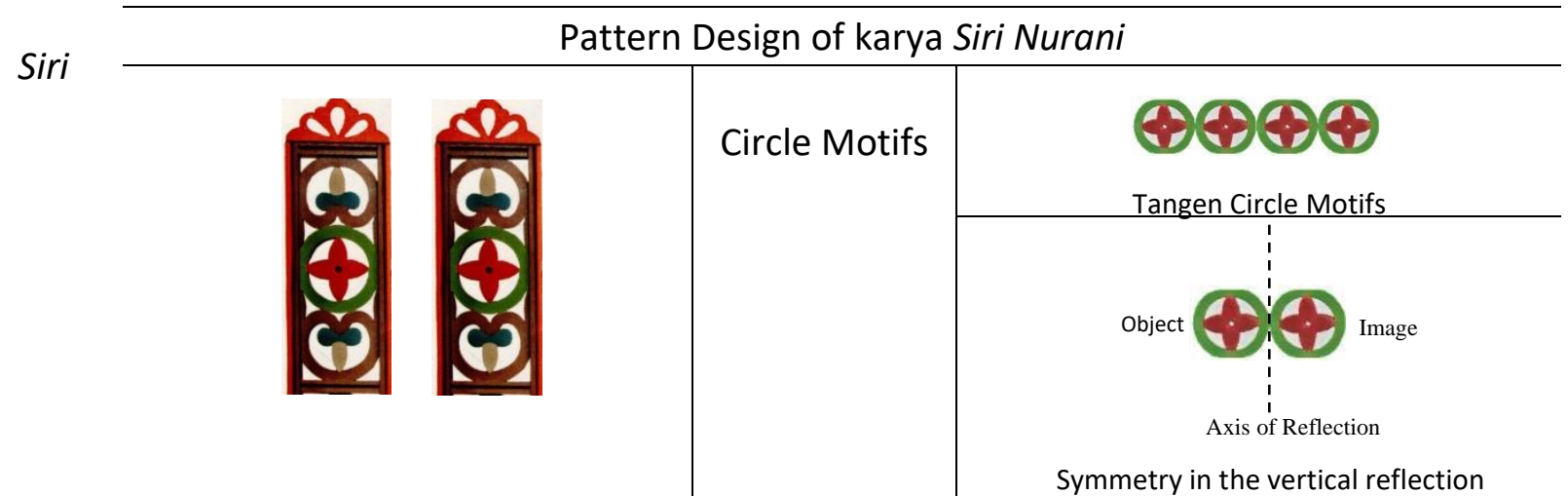

Nurani painting features the Tangent Circle motifs as a pattern design that features consecutive circle 
INTERNATIONAL JOURNAL OF ACADEMIC RESEARCH IN BUSINESS AND SOCIAL SCIENCES Vol. 10, No. 9, 2020, E-ISSN: 2222-6990 @ 2020 HRMARS

combinations. This motif has a black dot in a circle, and it forms a chain that connects in a line (Adnan Jusoh et al., 2011). In terms of size, these motifs are fixed in shape and do not have significant differences that show a line of parallel and continuous motif arrangement. Table 5 also explains the concept of symmetry of the process of image repetition through vertical reflection. The Tangent Circle motif (object) is reflected on the reflection axis and produces the Tangent Circle motif (image) in reverse without changing the original shape.

Table 6. Triangle motifs design by Siri Nurani

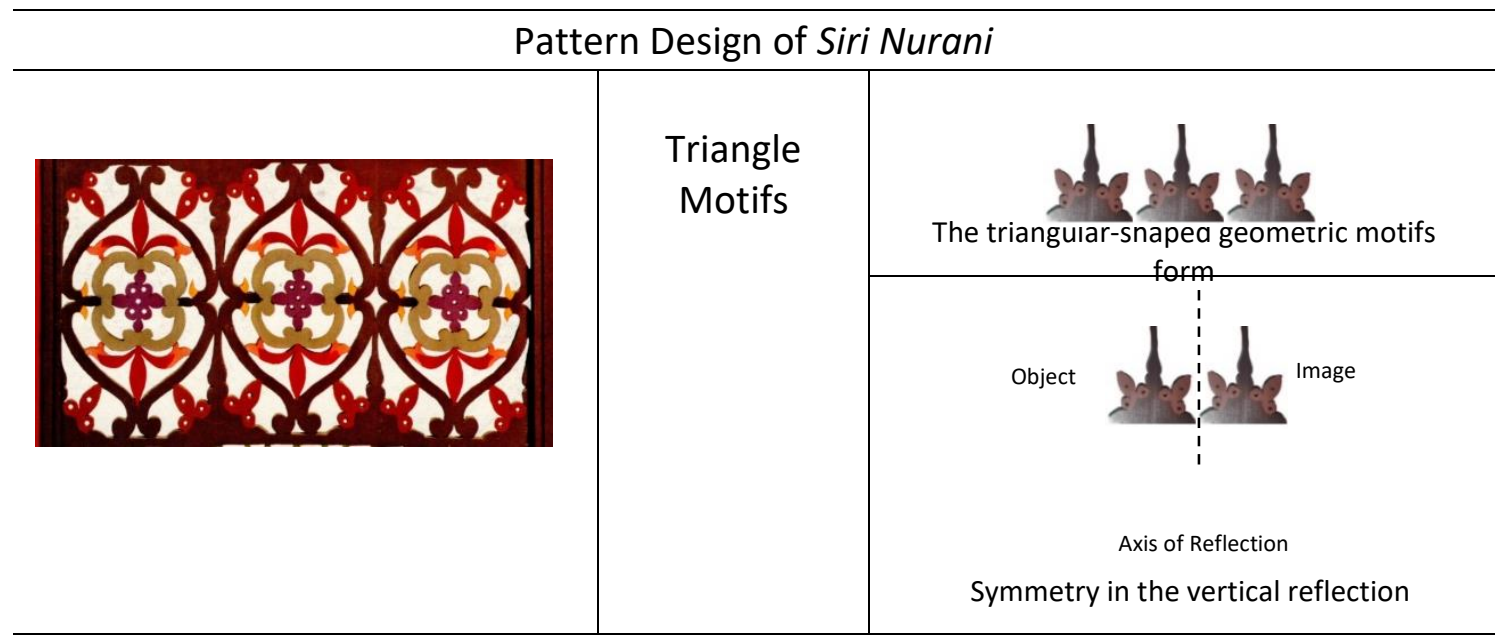

Triangular shape processing displays from three sides or three angles whose two borders are in the same length. The triangular-shaped geometric motifs form the basis of the Pucuk Rebung shoot pattern that rests on the creator of one universe, Allah Ta'ala. The triangular and most dominant Pucuk Rebung motif is used.

The position of the motif position shows the repetition of the image vertically. Most triangle motif is so dominant in the production of Malay artwork through the design and creativity of the artist. Table 6 also describes the axis of reflection located in the middle between the object and the image (triangular motif), i.e. the reflective object and the inverted image as in the mirror. Each plane on the reflected object and image has the same distance from the reflection axis. The selection of these motifs is still included in the category of shapes that are easy to sketch in paintings using wood carving material. 
Table 7. Design of Bunga Pecah Lapan motifs by Siri Nurani

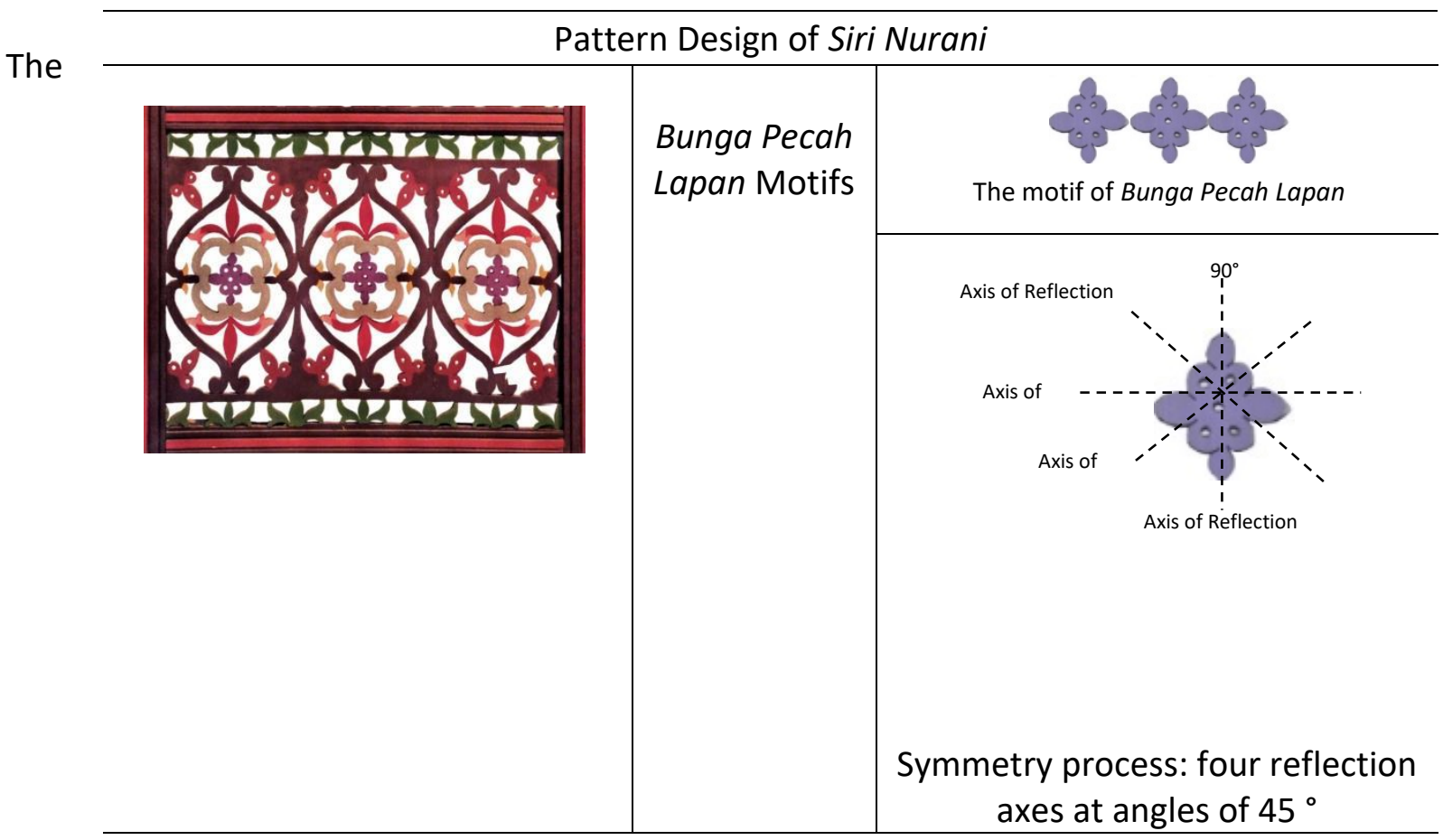

motifs of Bunga Pecah Lapan can be seen in the creation that displays the petals of the top eight views, known as Bunga Lawang, which is inspired by spices (Mohd Sabrizaa Rashid, 2009). The Bunga Pecah Lapan motifs is associated with the top eight view petals as in the table. It has eight petals or radial shape from the middle part of a dark brown star-shaped shape. These motifs can be broken down into specific parts, and patterns can be varied. While Table 7 also shows the concept of symmetry from the four reflection axes on the Bunga Pecah Lapan motifs. This process produces eight rotating angles of $45^{\circ}$ each. It is to form a pattern that has a diagonal balance through asymmetrical balanced composition. The design of this arrangement of these motifs in work is horizontal and sequential.

The symmetrical balance through the principle of geometry gives a formal picture in the processing of pattern elements arranged in the same shape, equal number, size, texture in the left and right parts of the work. The symmetrical balance can be seen in the plane of the two divisions as a plane of symmetry, which are reflection and mirroring (Abd Rashid Ismail, 2014). The beauty of mathematical processing in geometric measurements as the main component of this work, it highlights the balance in the arrangement of motifs that show the concept of continuous mapping. 
Table 8. Symmetry Balance

\begin{tabular}{c|c|c|}
\hline \multicolumn{3}{c}{ Symmetry balance by Siri Nurani } \\
\hline
\end{tabular}

Table 8 describes the carving components in the creation of Siri Nurani, fillifing the majority of the space in work. The design of the Siri Nuranishows a symmetrical measurement balance on a line of reflection axis where each engraving showed is balanced and equal to the overall composition in creation. Balance can be seen in the emphasis on motif design in works produced harmoniously through the use of artistic elements. Siri Nurani(1996) is also a work whose design is vertical to form the structure of the window leaf construction, and it is produced in symmetrical measurements so that it can be opened and closed. Selection of appropriate and contrasting colour matches to display the subject's perspective and balance in the workspace

\section{Unity Principles In Symmetry}

Table 9. unity of repetition patterns

\begin{tabular}{c|c}
\hline \\
$\begin{array}{c}\text { Horizontal repetition of } \\
\text { motifs }\end{array}$ & Vertical repetition of motifs \\
\hline
\end{tabular}

Unions in work are formed as a result of the layout of geometric motifs and flora arranged horizontally or vertically, which highlights the even and systematic symmetry repetition. The combination of materials used forms a harmonious composition through the layout of planes, looks, shapes and colours. The use of geometric and organic motive in the processing of works reflects unity through kerawang motifs. The symmetry that pays attention to the neatness of materials arranged in a geometric frame describes the sensitivity as well as the skill of producing beautiful works. Each pattern connects and is connected with other patterns in the work of Siri Nuranias a starting point to the production of the composition of the creation (Abd Rashid Ismail, 2014). 
INTERNATIONAL JOURNAL OF ACADEMIC RESEARCH IN BUSINESS AND SOCIAL SCIENCES Vol. 10, No. 9, 2020, E-ISSN: 2222-6990 @ 2020 HRMARS

\section{3) Textile Arts}

The beauty of songket patterns and motifs is rich in mathematical values and geometric patterns. Most weavers, especially from the older generation, are unaware of the existence and application of mathematical concepts in their artwork. Songket weaving is a symbol of refinement of the Malays inherited since time immemorial.

Table 10. geometrical identification of traditional Pucuk Rebung

\begin{tabular}{|c|c|c|}
\hline \multicolumn{3}{|c|}{ Songket Sampin Based on Geometric Pattern } \\
\hline $\begin{array}{r}\text { Geometric patterned songket } \\
\text { Ge* }\end{array}$ & $\begin{array}{l}\text { the } \\
\text { triangular } \\
\text { shape of } \\
\text { pucuk } \\
\text { rebung }\end{array}$ & 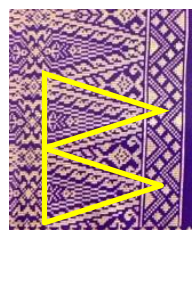 \\
\hline
\end{tabular}

Table 10 shows the motifs of Pucuk Rebung often found on songket, and its use has been raised through the production of songket arranged in waves. It is a symbol of fertility that has strength and is sketched in a triangular shape because the pattern refers to the motifs that can be seen on the top and bottom lines of the cloth head (Abd Rashid Ismail, 2014).

Table 11. Symmetrical design: the process of transformation

\begin{tabular}{c|c|c}
\hline \multicolumn{2}{c}{ Songket Sampin Based on Geometric Pattern } \\
\hline $\begin{array}{c}\text { Symmetrical } \\
\text { design: the } \\
\text { process of } \\
\text { transformation }\end{array}$ \\
$\begin{array}{cc}\text { Geometric patterned } \\
\text { songket }\end{array}$ & \\
\hline
\end{tabular}

Table 11 shows the symmetrical design through the process of symmetry produced in songket weaving. The translation process displays the object being on a basic unit of repetition in a linear plane of symmetry. The object moves the entire image at a fixed distance in a fixed direction. The production of images motifs repeatedly slides to the right or left but still maintains the same orientation as the table above.

While reflection is an object that moves to produce the same image, there is an axis of reflection located in the middle, the axis of symmetry of an object and image. Image production is reversible but still the same in terms of shape and size. It occurs when the object (motif) reflects, and the image (motif) reverses as in the shadow of the mirror along the line vertically and horizontally. 
Table 12. Bunga Lawang atau Motif Bunga Pecah Lapan motifs

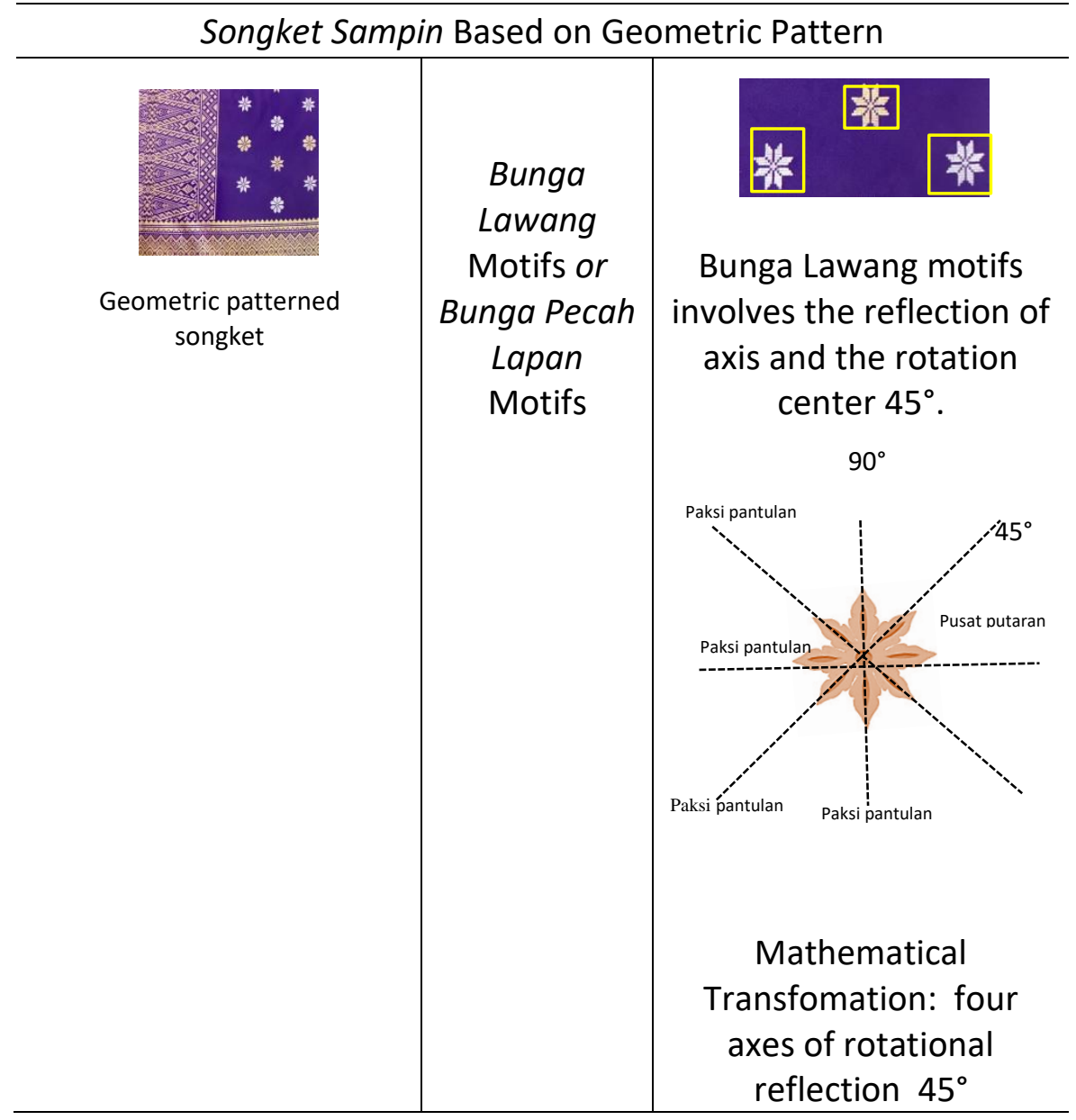

Table 12 shows the design of the Bunga Lawang motifs or the Bunga Pecah Lapan motifs also identified in the songket sample used. It has four axes of symmetry, and this motif forms eight angles when each repetition undergoes a $45^{\circ}$ rotation around the centre of rotation in the middle of the motif with a rotation of $360^{\circ}$ (Nor Maizan Abdul Aziz \& Rokiah Embong, 2016).

\section{4) Wood Carvings}

Carving is an outstanding manuscript in the study of the history of Malay left in the form of sculpture (Norhaiza Nordin, 2010). Islamic fundamentalist ideology has led to the adoption of Malay wood carving art in buildings, by producing new motif-based elements such as geometric shapes, flowers, buds and foliage plants (Othman Yatim, 2000). The geometric motifs continue to grow in line with the acceptance of the Malays to Islam. When animal motifs were not allowed, the sculptor began to 
INTERNATIONAL JOURNAL OF ACADEMIC RESEARCH IN BUSINESS AND SOCIAL SCIENCES Vol. 10, No. 9, 2020, E-ISSN: 2222-6990 @ 2020 HRMARS

apply geometric patterns in the carvings. Usually, these geometric motifs are combined with calligraphic motifs. However, there is also geometry combined with flora motifs (Ismail Said \& Ahmad Saifuddin, 2001). Most wood carvings feature static ventilation hole panel frames in square compartments. Geometric motifs can be seen as a result of the formation process that occurs in the activity of repeating images that are arranged in a structured manner that is in the order that has been set to form an arrangement of patterns (Haziyah Hussin, 2006).

Table 13. The wood carvings based on the geometric

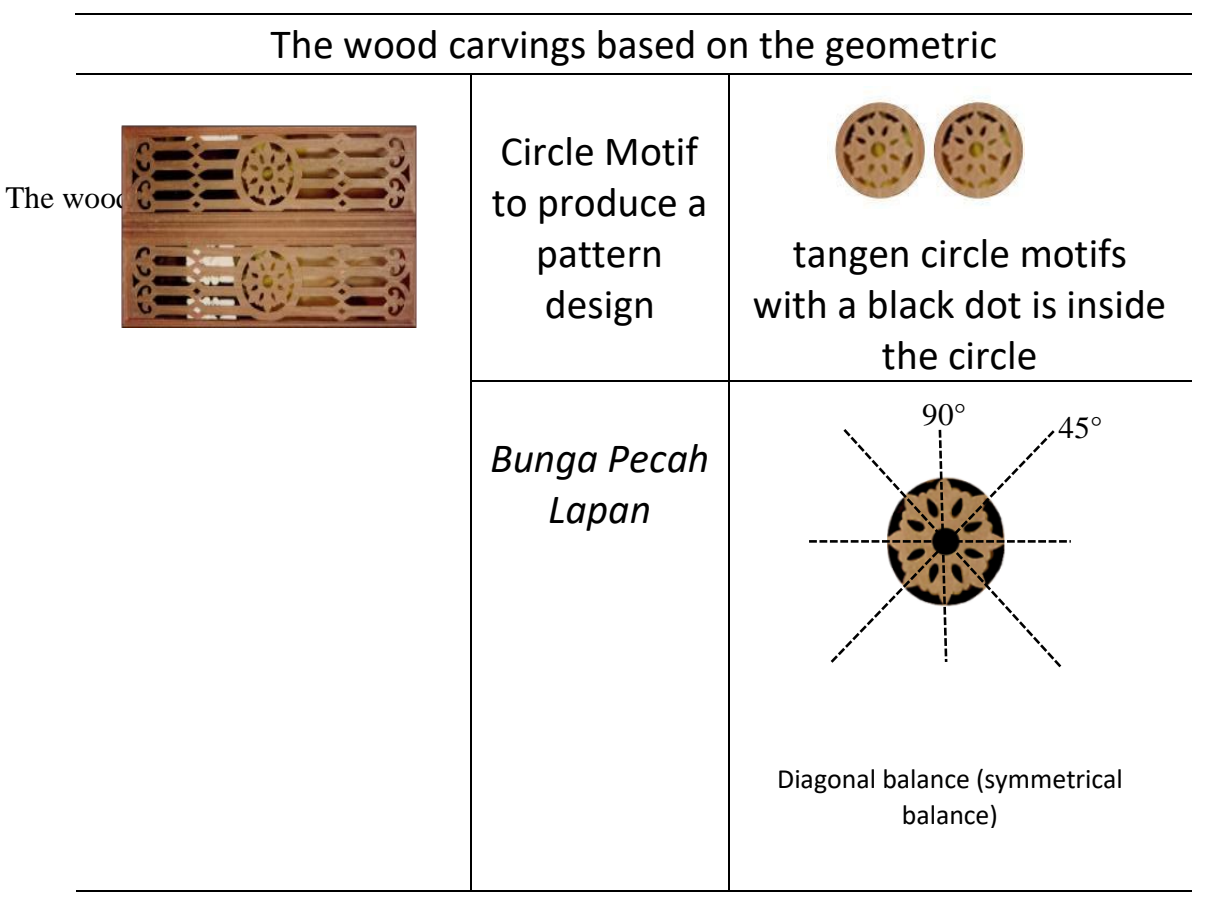

The wood carvings on the walls in the table above are based on the geometric appearance that highlights the Bulatan Motif to produce a pattern design, and it is one of the aspects that characterize the metaphor of the artist in the carving. The shape of the circle creates a balanced composition through the beauty and is used as a material in the production of creations. The images produced in the wood carving also use natural motifs based on the selection of the Bunga Pecah Lapan. It features eight petals from the top view. There are four axes of symmetry that form eight equal angles. Each pattern repetition has a $45^{\circ}$ angle around the centre point to produce a $360^{\circ}$ rotation.

Table 14. Transformation Process

\begin{tabular}{c|c}
\hline \multicolumn{3}{c}{ Wood Carving based on geometric pattern } \\
\hline wood carving on the wall & $\begin{array}{c}\text { Symmetrical } \\
\text { design: the } \\
\text { process of } \\
\text { transformation }\end{array}$ \\
\hline
\end{tabular}




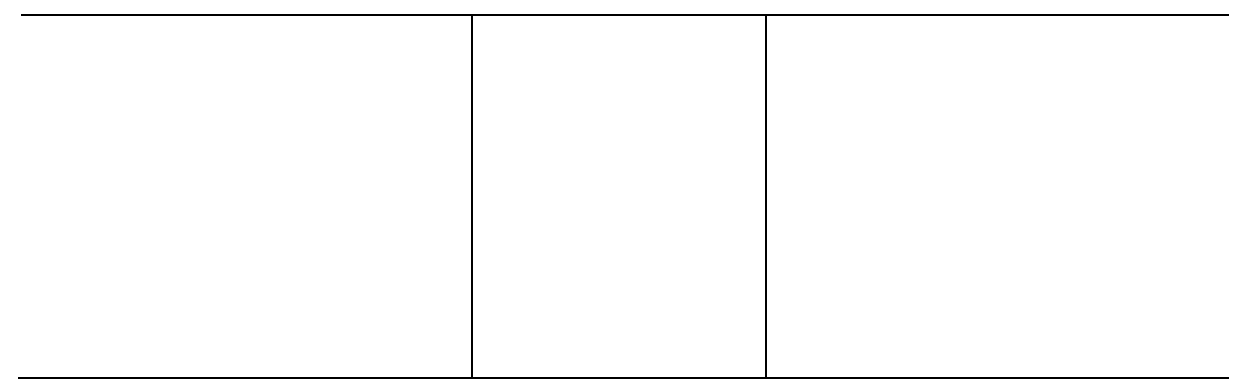

Table 14 describes the process of image repetition that occurs in the art of wood carving, i.e. vertical reflection. A reflection is a transformation in which all the points on an object (motif) are reflected on a straight line known as the reflection axis. The gap between the object to the reflection axis must be equal to the distance between the image to the reflection axis, and the straight line between the object and the image must be perpendicular to the reflection axis. The orientation of the image resulting from the reflection of the object (motifs) in the wood carving is not changing its position. While the resulting angle of rotation in the wood carving above is a transformation that rotates all the points in a plane at a point through an angle and in a predetermined direction. The point is known as the centre of rotation, and its angle is the angle of rotation. The shape, size and orientation of an object do not change after rotation.

\section{Conclussion}

The conclusions from this study aim to look at the symmetric analysis approach underlying the ethnomathematical context. It is identified through application of the design through the use of patterns and motifs handwork of traditional Malay concept of art through weaving, painting, songket and wood carvings. The study also shows the factors that support the relationship between formalistic aspects and principles for design symmetry traditional Malay arts to create a good research. Indirectly confirms that the Ethnomathematics concept of strength in traditional Malay elements and adapted in the handwork of art. Mathematical thinking and skills have long existed among art activists in the production of a combination of beautiful and symmetrical motifs. Processing of artistic and mathematical thinking is an attempt to show that mathematics is no stranger to the Malay art, even entrenched in various branches of mathematics. Art and mathematics are inseparable, and they are formed from humans and ideas. It is hoped that the results of this study can encourage the community to appreciate the beauty of the creation of art from a different perspective that is in terms of the beauty of mathematical concepts and values found in the motifs and patterns in work as well as the implicit and explicit mathematical abilities in the art itself.

\section{References}

Ismail, A. R. (2014). Kesenian Dan Fabrik Melayu: Alam Sebagai Motif Kraf Tangan Fabrik Melayu tradisi. Shah Alam: Penerbit Universiti Teknologi Mara.

Jusoh, A., Sauman, Y., \& Ramli, R. (2011). Gendang Gangsa di Asia Tenggara: Tinjauan terhadap Motif Berunsur Geometri. SARI: Jurnal Alam dan Tamadun Melayu, 29 (2). pp. 21-44. ISSN 01272721. 
INTERNATIONAL JOURNAL OF ACADEMIC RESEARCH IN BUSINESS AND SOCIAL SCIENCES

Vol. 10, No. 9, 2020, E-ISSN: 2222-6990 @ 2020 HRMARS

Hussin, H. (2006).Motif Alam Dalam Batik Dan Songket Melayu. Kuala Lumpur: Perpustakaan Negara Malaysia.

Said, I., \& Saifuddin, A. (2001).Spesis-Spesis Kayu Dalaman Ukiran Melayu. Skudai: UTM Press.

Ahmad, J., \& Idris, S. R. (1996). Ukiran Melayu.Petaling Jaya: Penerbit Pinang.

Ismail, M. R., Tarmizi, R., Ayub, F., Yusof, N., \& Kartini, S. (2012). Seni Warisan Melayu: Suatu Manifestasi Etnomatematik. Rampaian Etnomatematik. Universiti Putra Malaysia: Institut Penyelidikan Matematik.

Ismail, M. R. (2004).Etnomatematik. Matematik Merentas Tamadun. Falsafah Pengajian Sejarah Matematik. Kuala Lumpur: Dewan Bahasa Dan Pustaka.

Rashid, M. S. A. (2009).Cadangan Kaedah Kod 'S' Bagi Penamaan Dan Penentuan Motif Bunga Ukiran Melayu Dalam Proses Inventori. Kertas Kerja Ini Telah Dibentangkan Di Persidangan Antarabangsa Kesenian 2009 - Seni Dekorasi : Pelestarian \& Pembangunan, Anjuran Akademi Pengajian Melayu Universiti Malaya, Hotel Singgahsana, Petaling Jaya.P.1-13.

Ismail, M. R., \& Atan, K. A.(2010). Mathematics in the Malay world Prior to the Arrival of Western Mathematics. International Conference on Mathematics Education Research (ICMER). P.729734.

Aziz, N. M. A., Embong, R. (2016). Mathematical Transformations and Songket Patterns.European Science publishing Ltd.

Nordin, N. (2010). Pengaruh Reka Bentuk Corak Dan Motif Dalam Seni Ukir Melayu.

Yatim, O. (2000).Mengukir Kegemilangan Lalu: Biografi Wan Su Othman.

Penerima Anugerah Seni Negara. (1997). Kuala Lumpur: Kementerian Kebudayaan, Kesenian Dan Pelancongan

Basaree, R. O. (2016).Simbiosis: Keharmonian Seni Tradisional Dan Seni Digital Kontemporari. Balai Seni Visual Negara. Kuala Lumpur

Basaree, R. O. (2008). The Frieze Pattern in Malay Wood Carving. Jurnal Perintis Pendidikan. Shah Alam: Universiti Teknologi, 43-47.

Ismail, S. Z. (2018). Reka Bentuk Kraf Tangan Melayu Tradisi. Kuala Lumpur: Dewan Bahasa Dan Pustaka.

Zamri, S. N. Z., Sarmin, N. H., Adam, N. A., \& Sani, M. A.(2014). Modelling Of Tudung Saji Weaving Using Elements in Group Theory. Johor: UTM Press. Jurnal Teknologi 1159-64, 70:5.

Anuwar, T. (2013).Falsafah Etnomatematik. Makalah Dibentangkan Di Seminar Ethnosains Akademi Sains Islam Malaysia (ASASI) Ke-2.Pusat Dialog Peradaban. Petaling Jaya: Universiti Malaya.P.1-4. 